DRAFT revised paper for special issue of Sociological Review, edited by David Studdert and Valerie Walkerdine, forthcoming, 2016.

\title{
(Re)Locating community in relationships: questions for public policy
}

Jane Wills

School of Geography, Queen Mary University of London, Mile End, London, E14NS

j.wills@qmul.ac.uk

\begin{abstract}
This paper argues that we should think of community as being about social relationships rather than a 'thing' that is 'lost' 'found' or to be 'made'. The paper draws on the philosophy of Roberto Esposito and the sociology of David Studdert to highlight the overlaps in their approaches to community. Both argue that community is ontological, as unavoidably 'with us'. The paper then draws upon two empirical examples to argue that this approach could enable a different kind of public policy in relation to community. Policy would focus on existing relationships as the starting point for any efforts to effect social change. The implications for contemporary debates about localism are explored at the end of the paper.
\end{abstract}

\section{Keywords}

Community; localism; public policy; social relationships; micro-sociality; civic participation; co-operative council.

\section{Introduction}

The UK's coalition government came to power in May 2010 promising to devolve greater political power to local communities. Prosecuted through what has come to be known as the localism agenda, Government has subsequently devised a number of new strategies to try and engage people in their own government. Local communities now have rights to neighbourhood planning, to register and protect community assets, and to challenge existing service provision. In addition, this agenda has cast its shadow over existing statefunded service providers and prompted a new round of experiments in community engagement, co-production and commissioning (HM Government, 2010). In the wake of the political pressure caused by the Scottish independence referendum in September 2014 much greater devolution has been promised to Scotland with wider implications for the 
geography of political power in England, Wales and Northern Ireland. While the genie of political devolution has been out of the bottle since the 1970s, the momentum is building for more (Kenny, 2014).

There are indications that the Labour Party is moving onto similar political territory. In developing their offer to the British people prior to the 2015 General Election, policy announcements promised greater powers for city-regional government and a recent party publication declared that politicians need to "be convenors, bringing people together to help them help themselves, finding solutions to their problems and improving their communities" (Cruddas and Rutherford, 2014, 36). Rather than using the state to solve social problems there is a growing tendency to argue that the state should enable local communities to develop their own solutions to pressing concerns (Wilson, 2012). As such, support for localism is growing across the political spectrum and as Hickson $(2013,408)$ suggests, this localist turn "has gone far beyond the perennial debate over the relative powers of central versus local government and, instead, should be seen as a radical ideological critique of the purportedly 'statist' form of British politics since 1945".

The localism agenda clearly raises important questions about community: about what we mean by local community; about what kind of action is both desirable and possible at the local level; about how such action might be realised; about the longer term consequences of such action should it occur; and about relationships between the state, citizens and communities going forward. This paper explores these issues and pays particular attention to the way that the philosophical arguments of Roberto Esposito $(2010,2013)$ and the sociological work of David Studdert (2005) might help us to think about community. Despite coming from different starting points and traditions of thought, both make an argument about the ontological status of social relationships which they capture through the language of community. Taking this approach allows us to recognise the ever-present community of life itself and the paper presents some new empirical material to illuminate the potential value of this approach in relation to public policy.

At a time when the Arts and Humanities and the Economic and Social Research Councils have promoted a new wave of research via the Connected Communities programme, it is a particularly good time to try and connect academic debate and research to public policy and practice in relation to community. To this end the paper reviews the history of ideas and 
research about community to suggest that: (1) academics clarify our understanding of the term community to focus on social relationships; (2) that we develop a sense of community as a condition of being rather than deploying the more traditional tropes of 'lost' 'saved' or 'to come'; and (3) use this approach to help shape public policy interventions such that they are more community-led. To this end, the paper makes the case for strengthening the intellectual ground on which public policy is formulated, implemented and understood, and makes this case in relation to the emergent practices associated with localism.

The paper is written in the hope that it will help to avoid the situation in which government and well-meaning professionals all too often see poor communities as either: (1) a 'blank space' in which apparently problematic residents can be ignored or simply 'decanted' away; (2) represented by official institutions (faith organisations, trade unions and local government for example) that can be brought into the service of the state in some way; or (3) a place where one-size-fits-all policy, designed by the people who know best, can be applied on the ground. These approaches have been dominant in public policy and in response, this paper calls for more careful thinking and practice, advocating that we develop a different understanding of community that can underpin a more sensitive approach to engaging with local populations, with very different outcomes for those on the ground as well as the more likely achievement of policy goals. In what follows I explore the academic debate about community and make the case for focusing on social relationships. I then use two examples to illustrate this approach to community and its potential application to public policy before going back to the wider debate about localism at the end of the paper.

\section{(Re)Locating community}

In popular discourse we tend to describe a community as a group of people. The group might be more or less conscious of their membership of this community, and it might be related to their shared place, identity or interests, but using the term community would indicate their unity around some axis of life. As such, community can be based on the imagined identifications of nation, ethnicity, gender or class, as well as the more intense relationships engendered by sharing space, face-to-face contacts and the close ties of family and friends. 
Social scientists have tended to adopt the same approach to understanding community (Crow and Allan, 1994). While there has been a division of labour in this work with anthropologists focusing on local culture, sociologists exploring processes of social change through the lens of communities, human geographers studying the importance of place and space, social psychologists unpacking the meaning and significance of feelings about community (Manzo and Perkins, 2006), and political scientists looking at the importance of notions of community in underpinning political institutions, organisation and practices (Finlayson, 2002), these disciplinary traditions have all used the concept of community to understand the intersection between individuals and the wider collective. In this regard, social scientific scholarship is also influenced by philosophical views about the position of the individual in society, and there are two dominant traditions of thought that have shaped the state of debate. On the one hand, there is an Aristotelian tradition that emphasises the inherently social nature of life (Arendt, 1958; Maclntyre, 1981; Taylor, 1989). On the other hand, strains of Hobbesian thinking have developed that emphasise competition and conflict between individuals. Taking the former position endorses an ontological role for community understood as comprising social relationships and I expand on this further below. In contrast, taking the latter position suggests that community is a means to contain conflict - most famously by adhering to the Leviathan of the state as a means to prevent mutual destruction - and seen through this lens, community is more fragile; it requires conscious creation and sustenance to continue and it is not inherent to life itself.

Such differences in philosophical thinking are extremely important to the way in which scholars approach the question of community and there are often elements of both underpinning social science research and public policy practice. However, given the role of the social sciences in providing technical expertise to the emerging welfare state, it has been all too easy to advocate for the skills of social scientists on the basis of the perceived failings of the social order (Savage, 2010). If community is weak, it is a social problem to which social science can be applied to find a solution. If, however, community is a condition of life itself, there is less of a case for social scientists being the technical cadre to intervene. Indeed, if we accept a different ontology, social scientists will need to grapple with a different rationale for their role in society and in this regard, some are developing more relationally-oriented approaches such as action research and co-production in which they 
contribute to the democratisation of knowledge-production rather than being part of an expert elite (Gergen, 2014; Harney et al, 2016; Gibson-Graham, 2008; Reason and Bradbury, 2001).

Such ontological foundations are often implicit rather than explicit, and may be unacknowledged by researchers themselves. However, the role of these divergent framings helps to explain why researchers can develop discordant perspectives on what might appear to be the same set of concerns. A Hobbesian discourse tends to frame an argument that community is under threat and vulnerable to decline (see for examples Bauman, 2001; Blackshaw, 2010), whereas those who focus on an Aristotelian argument about human sociability tend to argue that community is always with us albeit that it might be changing its form, as is explicated further below.

In this regard, this paper draws on two different - and unrelated but complementary sources of ideas that emphasise the Aristotelian approach with a focus on social relationships. Roberto Esposito $(2010,2013)$ has developed a post-structural philosophical reading of community while David Studdert's (2005) scholarship is rooted in the sociological tradition with a more obvious connection to debates about research, policy and practice. However, both make the case for thinking about community through the lens of social relationships, and in combination, their ideas demonstrate the potential power of ideas about community to shape public policy and practice in particular ways.

Esposito is an Italian political philosopher who has taken an etymological approach to understanding the question of community. He identifies the root of the word in the Latin munus which he translates as meaning the social obligation that accompanies gift and exchange. As he puts it: "The munus is the obligation that is contracted with respect to the other and that invites a suitable release from the obligation. The gratitude that demands new donations" (Esposito, 2010, 5). This reflects the way in which human beings are born through and in relationship with other people and as such, are born in a condition of relationship, debt and obligation to others that inevitably generates reciprocal relationships between people.

For Esposito, this means that community is about our social vulnerability and reciprocal relationship to other human beings rather than being a 'thing' to which we can join, affiliate 
to or identify with. Through this lens, community is inherent to our being rather than being a thing that is exterior to ourselves:

"[C]ommunity cannot be thought of as ... a corporation in which individuals are founded in a larger individual. Neither is community to be interpreted as a mutual, intersubjective 'recognition' in which individuals are reflected in each other so as to confirm their initial identity; as a collective bond that comes at a certain point to connect individuals that before were separate. The community isn't a mode of being, much less a 'making' of the individual subject. It isn't the subject's expansion or multiplication but its exposure to what interrupts the closing and turns it inside out: a dizziness, a syncope, a spasm in the continuity of the subject" (Esposito, 2010, 7).

In this regard Esposito highlights the way that the Latin root of community - munus - is also found in the word 'immunity' which can all too often be interpreted via a Hobbesian lens as being about efforts to keep the other/alien under control, and the boundary work needed to protect 'us' from 'them'. As Esposito $(2010,29)$ argues, the Hobbesian immunological vision of community may drive the state to try and "preserve individuals through the annihilation of their relation". However, just as community has its roots in relationship, so too, does healthy immunity whereby the system maintains good relationships with the organisms that live in and around us in order to protect bodily health. Without mutually beneficial reciprocal relationships, the body attacks itself in a condition of auto-immunity that can ultimately lead to death, just as a state can securitize itself to the extent that it undermines its own being (Esposito, 2013).

In this lexicon, community is about the unavoidable exposure of human beings to mutual dependency upon others. Building on the earlier work of Jean-Luc Nancy $(2000,1996)$, Esposito echoes his arguments about 'the singular plural'; that there is no being without 'being-with', and that life demands co-existence with others such that 'I' does not come before 'we'. The individual human being is in what Nancy refers to as a state of 'being-withothers'. By adopting this understanding of life and rethinking the language of community, it is possible to challenge the language of loss that characterises most analysis of community. Indeed, the power and resilience of arguments about the loss of community is striking. As Nancy $(1991,9)$ puts it: “The lost, or broken, community can be exemplified in all kinds of ways, by all kinds of paradigms: the natural family, the Athenian city, the Roman Republic, 
the first Christian community, corporations, communes, or brotherhoods - always it is a matter of a lost age in which community was woven of tight, harmonious, and infrangible bonds and in which above all it played back to itself, through its institutions, its rituals, and its symbols, the representation, indeed the living offering, of its own immanent unity, intimacy and autonomy". In recognising but rejecting the power of this narrative of loss, Eposito and Nancy urge that we rethink community as 'being with' and that this reflects our “ontological sociality" or 'being-in-common' (Nancy, 1991, 28). As Heidegger put it in Being and Time (quoted in Esposito, 2010, 92): "the world is always already the one that I share with others. The world of Da-sein is a with-world. Being-in is being-with others".

If more widely adopted, this approach would allow scholars and practitioners to see and recognise the ontological status of community. It would focus minds on the necessary relations between people and the potential of all the already existing reciprocal relationships that underpin everyday life. In the discipline of human geography these arguments have already been used to highlight the more-than-human relationships that underpin the human condition (see for example, Bingham, 2006; Greenhough, 2014; Hinchcliffe and Whatmore, 2006; Popke, 2009, 2010) but they have yet to be developed in relation to debates about community and public policy (although an early intervention was made by Panelli and Welch, 2005).

In this regard, it is useful to explore David Studdert's (2005) sociological approach that comes to similar conclusions to those outlined above. In a rejection of Cartesian thinking, Studdert has similarly argued that the individual is not prior to community and that community is not about the dominant tropes of 'loss' nor 'salvation'. He also makes a powerful case for understanding community in its own right rather than as an instrument for the state or others to do their business. But while he too argues that community is an ontological given, Studdert goes on to focus on the way that community is manifest in everyday inter-relationships. As such, this is a more performative understanding of community. In making this case Studdert draws heavily on the ideas of Hannah Arendt (1958), herself strongly influenced by Aristotelian thinking, to emphasize the importance of action. As he explains: "community can only ever be in the 'actuality of the moment' ... community is a living thing, a coming into being, not an abstract macro formation with laws unto itself outside of the sociality of the space of appearance ... there is no community 
outside of its continual enactment, re-enactment, creation and recreation within every instance of society" (Studdert, 2005, 161). Rather than the focus on 'being with,' Studdert's approach emphasises the way that social relationships - and hence, community - is constantly reproduced and remade in the everyday spaces where inter-personal encounters take place and as such, it is always particular and dynamic (see also Howell, 1993).

Studdert's approach suggests a research and policy agenda that would focus on community as located in the 'microsociality' of local relationships. In relation to the dominant discourses of social science and public policy, it would mean rethinking community as being about relationships not a 'thing' that is to be made. By fusing the philosophical positions of Esposito (and Nancy) with Studdert's notion of microsociality, community can be understood as an ontological given but also as something we reproduce through located and embodied performance and practice. While we are born through and in social relationships, each of us are differentially open to relationships with other people and things, the context and culture in which we live will make a tremendous difference to the number, intensity and outcomes of those relationships. As such, our personal communities (and the tendency for or against autoimmunity) are shaped by a host of factors such as existing relationships, personality, place, opportunity, experiences and power relations (and for a flavour of a strong body of emerging research into the way that particular places shape social encounters now being developed in human geography see Bissell, 2010; Jones et al, 2015; Laurier and Philo, 2006; Koch and Latham, 2012). Using this lens to understand community in relation to public policy would demand: firstly, a recognition that social relationships and thus community always exists (it is not 'dead, dying or future but living' (Studdert, 2005, 193); secondly, a focus on the quality and sensibility of social encounters, their sustainability, and their outcomes; with a view to thirdly, working with people on the basis of their own relationships and interests rather than imposing something new from above or beyond.

Thus rather than being about a melancholic search for a lost community or a utopian dream of a new Jerusalem, attempts to understand community would start by focusing on existing relationships without assuming any necessary or desirable unity between individuals and groups of people. Furthermore, this approach would help us to take the individual more seriously, freeing up our investigations from the abstractions used to construct the social 
groups that are so beloved of social scientists (and most obviously, the triad of 'class' 'race' and 'gender'). Indeed, this approach would have no space for so-called communities that are reflections of abstract categorisations (and most obviously, it would mean scrutinising categorisations such as the 'gay community' or the 'working class community' and using more precise language in this regard). If people are always in relationship, we would start from those relations rather than making a priori assumptions about the character and meaning of those relationships, the ones that matter and the ones that don't.

The factors that shape our social relationships have long been recognised by previous generations of social scientists. Indeed, there is a strong Aristotelian strand of thinking in the sociological tradition that developed with Durkheim and in this regard, there is much in the existing literature which supports this approach to community (see for examples, Challenger, 1995; Calhoun, 1988; Day and Murdoch, 1993; Sampson, 2012; Wellman, 1996). While sociology has been apparently preoccupied with the narrative of community decline, there have always been co-present glimmers of an alternative perspective which recognise the inherent sociability of human life. Moreover, by identifying this intellectual continuity over time, it is easier to make the case for the ontological status of community and its implications for public policy today.

Coming of age alongside the processes of mass industrialisation, rapid urbanisation and increased population mobility, sociology has always been a discipline preoccupied by changing social forms and their implications for human well-being. In the nineteenth and twentieth centuries liberalising societies provided new opportunities for people to exercise increasing choice over their lives and as they were pushed and pulled by the market, they moved to cities and joined very different kinds of societies. In the most famous sociological exposition of this process of social change, Ferdinand Tönnies (1887) differentiated between the Gemeinschaft of small scale rural communities with the Gesellschaft of the new urban societies. Whereas the former were associated with face-to-face relationships cemented over time, the latter were places where it was possible to live amongst strangers. The new school of Sociology at the University of Chicago, founded in 1892 and led by Albion Small, famously attracted a group of scholars who used this trope of social disorganisation to go out and make sense of the changing city around them. Chicago became a laboratory for understanding the way in which new immigrants - internal and international - were able to 
move to the city and make a new home. As pre-existing social mores and traditional cultures were undermined by new ways of living, these sociologists deployed ethnographic techniques to understand how people made sense of this new social (dis)order.

Interestingly, however, despite adopting the language of social decline and (dis)order, these scholars were focused on the ways in which people were forging new forms of social organisation. Following hard on the heels of Durkheim who had sought to find ways to foster social relationships that could lay the foundations for a renewed solidarity, most notably around occupation, these scholars were committed to social solidarity and its implications for democracy. Indeed, Park, Burgess and Shaw argued that as people were confronted by the chaos of the city, and the dislocation of their old social order, they would inevitably be drawn into new forms of social relationship and organisation. For Robert Park $(1925,16)$, this involved "a solidarity based, not on sentiment and habit, but on community of interests" and as an example he cited the communities that were generated around schools. By having a shared interest in the welfare of children he argued that: "something like a new neighbourhood and community spirit tends to get itself organized" (op cit. 1925, 24).

Anticipating later arguments about the importance of social capital, Park went on to highlight the ways in which 'new agencies' or institutions grow up to meet the challenges of the new society - including settlement houses, youth projects and welfare organisations thereby creating new forms of social organisation. Park made a plea for professionals to get their hands dirty in helping to form new organisations in order to engage the urban population in understanding and acting upon their shared interests. While these sociologists used a different language to that deployed by more recent scholars of community, they were similarly attached to the fundamentally social nature of being.

It was Ernest Burgess (1916; see also Park et al., 1925) who took up the challenge of developing the practical - and political - application of these ideas. He developed a vision of the 'social survey' whereby trained sociologists would work with local communities to map their local institutions and social networks, to identify shared interests and develop the capacity to act in defence of such interests. In this guise, social science was a vehicle for understanding social change, social relationships and the development of people with the technical skills and aptitude to intervene in local community life. Indeed, Burgess argued 
that sociologists should: (1) train local people to do a survey of their community; (2) educate local leaders about social problems; and (3) "develop a core group of leaders prepared to organize for social advance" (Burgess, 1916, 12). This approach was later realised in the work of Saul Alinsky, a post-graduate from the School of Sociology, who set up the Back of Yards Neighbourhood Council in Chicago in 1939 before going on to found the Industrial Areas Foundation in 1940 (Alinsky, 1941). As such, broad-based community organising that recognises existing social relationships and their potential to underpin political change has its roots in the theory and practice developed by Chicago university sociologists a hundred years ago (Engel, 2002; Harney et al, 2016; Wills, 2012).

This tradition of thought and practice reflected the pragmatist philosophy of William James [1842-1910] and John Dewey [1859-1952] who argued that ideas were tools for action without foundation in an ultimate truth. As such, and anticipating the post-structuralism of today, community was an idea that helped social scientists and local people work together to engage people in democratic experiments (Bernstein, 1992; Rorty, 1989). The Chicago School sociologists had a vision of human life as necessarily social and in some ways, although in a different register, they anticipated the arguments made by scholars like Esposito and Studdert outlined above. Above all, Park and his colleagues approached the city as a place in which people had social relationships with each other and at a time of change, those social relationships were creative of new social formations with implications for political life.

Interestingly, it is later sociological studies that have tended to reflect a less Aristotelian approach to social life. By the late 1950s, the idea of the local neighbourhood came to be rejected as ideological cover for the operation of vested interests in society as well as the academy (Dennis, 1958). Although a series of community studies were pioneered in the United Kingdom during the late 1950s and 1960s, they were often understood and interpreted not on their own terms but as windows on to wider processes of social change, and these places came to be seen as local exemplifications of the social abstractions demanded by social theory. Indeed, Savage (2010) locates these studies as part of a national renaissance of a new kind of sociology associated with an empirical science of society such that they "defined the local as a site of social change, rather than as location in a wider 
landscape, they abstracted the local study from its environment, and so mobilized them as displaced exemplars of the nation" (Savage, 2010, 140).

In his reflections on his own engagement in this body of research, Pahl (2005) has highlighted the way in which he tended to approach the field as an arena to test out the concepts generated by disciplinary debates rather than as a space to generate ideas based on his and his respondents' experiences. As an example of this phenomenon, Charles (2012) notes that she undertook her re-study of an earlier community study in Swansea expecting to be able to illuminate the declining importance of place and community, only to find that many of her respondents retained strong family attachments to the local community across the 40 years of research. Even though the respondents tended to describe a community in decline, they simultaneously reported a rich locally-oriented social life. As such, the boundary drawing involved in such narratives of decline - often highlighting divisions between 'old' families and newcomers - can be understood as a way to cement a sense of local belonging and shared identity in the present as much as being accurate descriptions of social decline (see also Charles and Davies, 2005; Wellman, 1996). Moreover, this community re-study pointed to the importance of social relationships and everyday social encounters. It reflected the continued importance of community despite the way in which people might talk about their relationships and the lexicon that sociologists choose to deploy. Indeed, the language of sociologists and policy makers is often complicit in popularising discourses of community decline (and the debate about declining social capital has been particularly powerful in this regard, see Putnam, 2000 in contrast to Hall, 1999).

In many ways, my own discipline of human geography has moved further from latent Aristotelianism than sociology, at least in relation to debates about community. Just as Savage (2010) describes in relation to the fate of community studies in sociology, human geographers have studied localities in relation to what they tell us about wider processes of social change but also how they relate to other places. In a bid to reject spatial fetishism, and in the wake of a widespread adoption of Marxism and ontologies of networks, places have been understood in relation to other places, rather than being significant in their own right. As Clarke $(2013,499)$ puts it in a review of this field, local communities are now "seen as open, porous, permeable, heterogeneous, incoherent, dynamic and incomplete; products of mixture, encounter, intermingling; characterised by juxtapositions and co-presences; sites 
of distanciated connections; marked by other times and places and implicated in numerous networks." Representing this view, Amin and Thrift $(2002,4)$ have called on human geographers to move beyond "a politics based on nostalgia for a lost past of tightly knit and spatially compact urban communities". They posit a politics that recognises the mobility of urban populations, the importance of networks and the reduced salience of propinquity. In this lexicon, there is little use for an idea like community and even less for the notion of a 'geographical community' although there has always been dissent on this front (Bonnett, 2010; Day and Murdoch, 1993; Devine-Wright, 2015; Tomaney, 2013; Wills, 2013).

If, in contrast, we adopt the position that community is about the social relationships that support life itself and as such, community is necessarily located in time and space, place remains important. Even if people engage as a 'newcomer' practising what Savage and colleagues refer to as 'elective belonging' rather than being there from birth, places provide an important context for the microsociality of life (Savage 2010).

If adopted in relation to public policy, this approach to community could have very important effects. Rather than trying to (re)create community through blueprints developed elsewhere, often over the heads of local people, politicians and practitioners would respect the community that already exists and allow local people the space and resources to start where they are. Indeed, rather than starting with what the state will do 'for' people, politics would be about exploring what the people are already doing and the obstacles that get in the way. As such, this argument chimes with some of the narratives around localism that claim to be about 'freeing up' people to identify their own problems and decide what they can and might do about them. However, rather than casting this as a regressive form of 'spatial liberalism' (Clarke and Cochrane 2013) - with negative associations with neoliberalism (Peck and Tickell, 1994; 2014) - this approach would be welcomed. As Walkerdine and Studdert $(2013,7)$ put it in relation to the localism agenda: "For localism to succeed there needs to be a paradigmatic cultural shift in the way that governments view community, how it assists it, how it conceives it and how they view and measure it. In many instances the basic requirement for government at all levels is to simply get out of the way."

The model of community outlined here helps to provide an alternative lens for understanding local social life and it points to a different kind of public policy with a different role for the state. However, rather than 'simply getting out of the way' it would 
demand a new way of thinking and a very different approach to providing support for community work. I now illuminate this further with two empirical examples of communityoriented practice. The first illuminates the extent and importance of social relationships in a poor inner city neighbourhood, and the potential for using existing relationships as a way to create local change. The second illustrates how it is possible to work with existing individuals and their interests to create new projects that generate social relationships for positive change. This model starts with local individuals as the bedrock from which to extend social relationships within any place.

\section{Researching localism}

The material reported in this paper is part of a larger project to explore emerging localism in England, funded by the Leverhulme Trust, between 2012 and 2015. The aim of the project was to explore the development of the localism agenda and its wider implications for thought and practice, but in relation to the empirical work undertaken, the project has included focusing on changes to the way in which publicly-funded bodies operate at the local level through the development of Neighbourhood Community Budgets; the new rights enshrined in the Localism Act (2012) including a number of case studies of neighbourhood planning in different parts of the country; changes to the way that Local Government interacts with its citizens by looking at the development of a cooperative council; as well exploring the tradition of broad-based community organising and the way in which this can provide a mechanism for voice and engagement in public life. This latter part of the project was based on a long-running involvement with the local alliance that is affiliated to London Citizens (and Citizens UK) in east London. Through this engagement, I met a number of the key community leaders in the geographical area around Queen Mary in the east end of London. I witnessed some of their work and interviewed a number of them about what they do, and why.

In what follows I focus on the activity of one of these community leaders; a Salvation Army captain, Nick Coke, who I have known since 2005. While it may seem odd to focus on one respondent, Nick exemplifies the approach to community advocated in the argument made in this paper. He and his wife moved to the area in 2003 and they subsequently focused on 
building relationships with local people - and working with the grain of local microsociality on one estate. Rather than being located in a building, or working to create an institution or provide a particular programme, they simply sought to create relationships with local people. Their ministry was focused on a small geographical area and the people who lived there. Over time, they forged new relationships as well as facilitating links between people who hitherto did not know each other. Thus at one level, this was a very low level intervention compared to the dramatic national initiatives determined and directed by national government such as the New Deal for Communities project that was also operating on the estate during the New Labour years (Lawless et al., 2010). However, Nick's intervention illuminates the theoretical arguments made in this paper: community is present - even in areas that politicians all too often dismiss as poor, disadvantaged and/or problematic and worthy of intervention and 'improvement'; and people are already relating to each other while also being open to making new relationships through which new things can happen.

While Nick's work reflected his particular understanding of Christian mission, the second example was more obviously applicable to public policy work. The Open Works experiment, based in West Norwood, Lambeth, South London, ran for 18 months from early 2014. This was funded by Lambeth Council as part of its efforts to become a cooperative council and it represented one of a series of experiments in forging new relationships with residents and organised groups. In the foreword to the final report produced by the Cooperative Council Citizens' Commission that sat during 2010, the then Council Leader Steve Reed set out a vision for reshaping 'the settlement between citizens and the state by handing more power to local people so that a real partnership of equals can emerge' (London Borough of Lambeth, 2011, 1). This was about 'finding new ways in which citizens can participate in the decisions that affect their lives' and the council doing 'things with its community rather than ... to the community' (emphasis added).

In this vision for the local authority, citizens were envisaged as working alongside councillors and officers to make key decisions about how to achieve the outcomes desired. Indeed, as outlined in the Commission's final report: 'council staff and citizens cooperate together ... they work together to identify a problem, design a range of services that will tackle that problem, and then commission the right organisations to provide these services' (London 
Borough of Lambeth, 2011, 32). Rather than leaving policy and procurement decisions to staff and representatives in the town hall, the idea was to incorporate citizens into every stage of the process. This 'community-led commissioning' was to be critical to the 'stated desire to rebalance the power relationship between the citizen and the state in favour of the citizen, recognising that both sides bring particular skills and knowledge to the process' (London Borough of Lambeth, 2011, 33).

For Council Leader Lib Peck, this approach had to mean 'moving away from a consultation where you determine what's best and invite people to just respond to it, to a situation where you're saying well actually, if you're really honest, this is the scale of the challenge, how are we all going to pitch in and find the solution? ... There's been a very deliberate cultural change going on with councillors, with staff, with community to really try and level up the decision making process' (interview, 4.6.14). In so doing, the hope was that outcomes would be better, with the hoped-for additional benefits that come from improved working relationships, stronger sociality and increased civic capacity.

As part of this initiative the Council launched a number of experiments to develop this way of working and at the most radical end of the spectrum they funded Open Works in West Norwood(Civic Systems Lab, 2015). Led by Civic Systems Lab this was part of a series of projects or experiments to develop a 'local civic economy' (http://www.civicsystemslab.org/about/). Two coordinators (Tessy Britton and Laura Billings) were deployed from Civic Systems Lab and together with a small number of staff seconded from the Council, they worked from the shop front to meet local people, and explore their talents, interests and ideas. By then following up to help people realise at least some of their ideas for new projects, they were able to establish 20 different initiatives led by local people, using local resources, to make things happen, and these included projects around food, horticulture, crafts and trades (echoing wider arguments about the importance of making in creating social connections, see for example, Gauntlett, 2011).

As a more organised manifestation of Nick Coke's experience in Tower Hamlets, this project worked with existing people and existing spaces in the local area to make things happen. Rather than providing an established suite of services and expecting people to fit with the programme, the Council funded Open Works to provide a platform for local people to come up with their own ideas about the things they wanted to do, with the scope to then support 
them to make things happen. This represents a profound change in the relationship between citizen and state: from working top down, it moves the power to those on the ground.

In each case, my research involved site visits and interviews with the key protagonists which were recorded and transcribed. My interview with Nick Coke was conducted in my office on $17^{\text {th }}$ April 2014, and my interview with Tessy Britton and Laura Billings was held at the Open Works space in West Norwood, South London, on $15^{\text {th }}$ July 2014. I also attended a Civic Systems Lab workshop held in Norwich in January 2015 and this further illuminated their approach to the work. The publication of a large research report that documented the Open Works experiment alongside other developments in models of civic participation has also helped to evaluate the work that was done (Civic Systems Lab, 2015). Here, I use this research material to explore the ways in which our thinking about community can have a powerful influence on public policy. The way that Nick thought about community shaped his mission and its outcomes, and on a larger scale, Tessy and Laura were able to mobilise their ideas about community through the operation of the Open Works platform, as is explicated further below.

\section{Living community on the Ocean Estate in Tower Hamlets, East London}

When Nick Coke and his wife Kerry moved to the Ocean Estate s part of their ministry in 2003 , they were determined to create a different kind of church. Rather than having a building around which they could focus Salvation Army activities they decided to start with the people, their relationships and the organisations that already existed. They understood community to be about social relationships rather than the four walls of a church. When they moved into a house on the estate bought by the Army in 2003, they started from scratch and focused on relationship building, and as Nick explained: "we would say the whole community was our building". Having their own children later provided additional opportunities to interact with local parents and children, and grow alongside each other as neighbours, but in those early days, Nick and Kerry just went out meeting people on the estate. In their first year, Nick recalls that they decided "to hang out with people to kind of find out what it means to live here and who's here and all of that". 
At that time, local people expected them to move on (as other middle class and/or mobile people tend to do) or to set up some kind of project (as other 'do-gooders' who come and go regularly in the east end of London also tend to do). However, Nick and Kerry found an extraordinary density of local social relationships and they were also able to join locallyorganised groups that met in local facilities and this helped them to make new relationships. These activities included local football and cricket teams, and going to the Scout centre, the youth club, the older people's lunch club and the mosque. As Nick recalled, some local men "had a cricket team and I like cricket so I went along and just used to play cricket with them ... so I got to know loads of guys from the estate through that."

Over time, Nick and Kerry also started to organise their own events but they would use existing spaces - the football pitch, the local mosque, the youth centre and the Scout Centre - rather than having a separate space that they 'owned'. By putting on their own events, Nick argued that they were "creating community in our neighbourhood" by bringing people together, often across pre-existing divisions in the local social fabric. Indeed, a large part of their work was about making connections between people who wouldn't otherwise be connected. As Nick put it: "we're not saviours of the community but it's about recognising there's all this stuff going on and you have to be part of that and you have to know what other people are doing". Through their own activities and the opportunity to get to know people and then make further social introductions, Nick and Kerry helped people increase their social contacts. This facilitated friendships and support that wouldn't otherwise have happened. In some cases, these relationships helped couples stay together, and older people maintain their homes as well as providing new opportunities for people to work. Rather like the traditional parish church that would serve everyone in a geographical area, but in contrast, by starting with what exists rather than expecting people to come to them, this practice is something of a contrast to other forms of Christian ministry. Indeed, some of the fastest growing churches now work on the basis of recruiting "people like you". Using the example of some of the large and successful Evangelical churches that tend to recruit through personal networks, Nick argued that this created "monochrome churches". By working across a geographical area, like the Ocean Estate, rather than being based in one sector of society, Nick and Kerry's community relations were likely to be much more diverse. In addition, these relations were local. As Nick reported: "nobody drives to our church on a 
Sunday, we don't need a car park. There's a few that cycle and a few that walk but everybody is in Tower Hamlets ... and it means that everybody knows each other". While they didn't have a sharp geographical boundary around their patch, they were building and sustaining social relationships in a neighbourhood and the spatial proximity augmented the social connections.

Over the eleven years that they had been doing this work, Nick and Kerry came to see themselves "as sort of community chaplains" and people brought issues and problems to them. In addition, their local group had affiliated with the local chapter of Citizens UK and this allowed them to be part of a much wider network across the borough, the city and nation (and for more on this organisation see Wills, 2012). One of their members was able to win a living wage at his employer, a housing association, through campaigning with the alliance. Their membership of the alliance had also facilitated connections with students at Queen Mary and in 2013 they had engaged in a joint campaign for better lighting and improved safety at night. This political activity gave local people a wider set of connections and the potential for making change for the better. Having said this, however, the biggest local challenges were associated with rising housing costs and population mobility, and these were very hard to confront.

Indeed, Nick reported that the people and families who were renting and/or in better jobs had to move out of the area because it was so expensive if they wanted to buy their own home. In contrast, it was often those in the greatest need who remained in social housing on the estate and in some instances, these people were not able to get more involved on a regular basis. As Nick described it, these were people who: "can't give time, energy and ... they constantly have crises ... family issues a lot of the time, drugs related, family members with addictions ... definitely job stuff, not being able to get a job. Getting a job but only lasting in that job for a short time, that's really common". For Nick, keeping the more stable people was critical to being able to reach out to those in greater need but the wider economic situation meant that these more stable people were the ones at the greatest risk of being displaced. As the prices of property continued to rise, the social relationships they had built were constantly being undermined by geographical movement, and Nick was running just to stand still. 
Indeed, this geographical mobility posed existential challenges to their mission in the area and he was concerned for the future. As he explained: "I think the big challenge is how, in the changing nature of communities, how we're going to stay together, how we're going to be able to continue building community". Thus although the neighbourhood was the site of constant, and accelerating, change which could be construed as 'decline', Nick preferred to characterise this as the challenge of 'change'. The community was still comprised of existing social relationships - and their own work to sustain and enhance those relations - but this labour was threatened by the pressure of market forces and associated population change. Nick's vision of ministry as being about fostering social relationships was more difficult in the context of rising land and property values and high rates of population mobility. The context in which relationships were made thus had a very significant impact on their maintenance and impact. This focus on context is now further illuminated by the Open Works experiment outlined in more detail below.

\section{Open Works in West Norwood, Lambeth, South London}

Open Works operated in West Norwood, Lambeth, between 2014 and early 2015 to create the opportunity for local people to make new contacts and develop their ideas for local projects. Open Works operated through face-to-face contacts made in a shop and gallery space on the high street as well as via a website, email list and regular events. As Laura explained, they were "looking around at the skills and the resources that are in an area ... [to] make them visible ... and [to] start building networks". In the early days, as Nick found in Tower Hamlets, Tessy and Laura had to start by getting to know people, and to better understand the geographical area and the resources (spaces and groups) that already existed.

Through this activity, they began to get a feeling for the interests, skills and passions of local people. In contrast to other council services where there is a set programme and people are invited to become 'clients' of the service, or at the most active end of the spectrum, to help by fulfilling a particular role as a volunteer or a 'friend' of the library or the park, Open Works took a much less prescriptive approach. As Laura put it, in contrast to the set-piece civic roles on offer to local people (as consumer, representative, charity-provider or pain-in- 
the-neck) their work was "much more emergent, making use of underused resources, skills, people, time, ideas and aspirations" and while there were multiple outcomes from the work, there was no set programme for the work to be done. Indeed, the vision was to connect with people in place and then create new activity that was supported by local resources (see Figure 1).

[INSERT Figure 1 source: http://www.theopenworks.org/]

During the 18 months of the project Open Works engaged with about 1000 people and helped to support 20 different projects (see Table 1). To do this people were invited via both face-to-face and email contact, to regular potluck suppers at which it was possible to make introductions and identify shared interests. One example included connecting people who were keen gardeners with someone from the bus garage who then provided some ground for planting which was cleared by another group of people with learning difficulties who were supported by a local charity. Other examples concerned the identification of underused spaces for a range of creative activities such as cooking, gardening, woodwork and craft, and opening these up for local people. The vision was to create an alternative ecosystem of spaces and people such that: "people would be able to have a map and say, I can take part in a repair café or a trade school or a cooking project, or I can grow stuff [here] ... or I could help with learning a second language over there. [We want] to create a different participatory peer-to-peer network that doesn't exist at the moment".

Table 1: The Open Works projects, 2014-15

\begin{tabular}{|l|l|}
\hline Name & Description \\
\hline Trade School & $\begin{array}{l}\text { Teaching offered by local people in their area of skill, with food } \\
\text { and drink served. This involved } 42 \text { teachers/classes delivered in } \\
10 \text { different spaces. Skills taught included building websites, } \\
\text { beekeeping, guitar, tango, allotment planting, social media } \\
\text { skills, photography, sushi and singing. }\end{array}$ \\
\hline The Great Cook & $\begin{array}{l}\text { People offered a recipe for communal cooking at an underused } \\
\text { local kitchen and took the food home at the end. People } \\
\text { registered and agreed to bring one of the ingredients. This } \\
\text { involved 53 people in 11 sessions. }\end{array}$ \\
\hline Potluck Suppers & $\begin{array}{l}\text { People brought food to share in different spaces with the aim } \\
\text { of making new connections and linking projects. }\end{array}$ \\
\hline
\end{tabular}




\begin{tabular}{|c|c|}
\hline Start Here & $\begin{array}{l}\text { An ideas incubator for young people to develop project ideas } \\
\text { using local entrepreneurs to mentor start-ups. } 6 \text { young people } \\
\text { were involved with } 2 \text { projects developed (one in film and one in } \\
\text { fashion). }\end{array}$ \\
\hline BeamBlock & A yoga teacher offered free classes in local spaces. \\
\hline Bzz Garage & $\begin{array}{l}\text { Project to encourage bee-friendly planting in public spaces that } \\
\text { started with space outside a local bus garage but went on to } \\
\text { support other spaces. This involved } 56 \text { people in clearing the } \\
\text { site, planting, gardening and harvesting. }\end{array}$ \\
\hline Library of Things & $\begin{array}{l}\text { People donated unwanted things or shared under-used items } \\
\text { and skills hosted by a local library with a website. } 64 \text { people } \\
\text { gave items and } 20 \text { borrowed them. }\end{array}$ \\
\hline The Joinery & Links people with skills with local work opportunities. \\
\hline Festival of Ideas & $\begin{array}{l}\text { Publicity for Open Works through a festival day hosted across } \\
\text { various different spaces and } 270 \text { people attended. }\end{array}$ \\
\hline Open Orchard & $\begin{array}{l}\text { Encouraged planting fruit trees in public spaces. } 8 \text { spaces were } \\
\text { identified, each supported by a local group and the project } \\
\text { involved } 75 \text { people. }\end{array}$ \\
\hline Rock Paper Scissors & $\begin{array}{l}\text { A collective shop opened for time limited periods. This linked } \\
\text { the local L'Arche group with other local makers involving } 61 \\
\text { people in two shopping opportunities. }\end{array}$ \\
\hline The Stitch & $\begin{array}{l}\text { A regular meeting for people who wanted to knit, sew, tailor, } \\
\text { upholster and craft using L'Arche's facilities that involved } 51 \\
\text { people. }\end{array}$ \\
\hline Out in the Open & $\begin{array}{l}6 \text { weeks of activity organised and publicised to encourage new } \\
\text { engagement in Open Works. }\end{array}$ \\
\hline Civic Incubator & $\begin{array}{l}\text { A } 6 \text { week evening programme to support residents develop } \\
\text { project ideas and take them to the next stage. }\end{array}$ \\
\hline Play Street & $\begin{array}{l}\text { Linked to a national network of temporary street-closures to } \\
\text { allow children to play. }\end{array}$ \\
\hline $\begin{array}{l}\text { Department of } \\
\text { Tinkerers }\end{array}$ & $\begin{array}{l}\text { Using abandoned electrical items from Emmaus and the local } \\
\text { recycling centre to dismantle and create new things. }\end{array}$ \\
\hline Collaborative Childcare & A workshop to explore the idea of sharing childcare. \\
\hline Public Office & $\begin{array}{l}\text { A network of up to } 15 \text { freelancers who used different cafes to } \\
\text { meet and work together. }\end{array}$ \\
\hline West Norwood Soup & $\begin{array}{l}\text { A crowd-funding dinner held to support local projects. Half the } \\
\text { ticket cost covered the meal and the other half was for projects } \\
\text { that were pitched and voted on during the night. This attracted } \\
18 \text { people to the first event. }\end{array}$ \\
\hline
\end{tabular}

Source: Summary developed from information in Civic Systems Lab, 2015

Echoing the language of localism, these projects were about "citizens coming up and making something better, rather than asking someone else to make it better". And as such, these 
projects were about "enticing more people into public life" through their own contributions rather than what the state might want them to do. As one participant put it in the project research: “It hasn't felt like charity, and that's been very important. It's been everybody, there's been real people working together, and on an equal level. People have been sharing their knowledge and ideas and skills - someone putting an idea out there and people bouncing ideas back - and that's been really good" (Civic Systems Lab, 2015, 101).

Open Works provided a platform to allow this happen, and again, in line with Nick's experiences in Tower Hamlets, the leading protagonists were able to connect with local people, explore their ideas, energy and resources, and facilitate connections between them to create local change. However, to be successful these projects rarely 'just happen' and certainly not on the scale required to create significant change in an area. The Open Works project required a heavy commitment of time, energy and staff salaries to make and sustain the relationships and facilitate the new projects that emerged from the work. Largely unrecognised in official discourse, this is the labour of community development and in this initiative, it was being consciously amplified for policy ends. In this regard, the Open Works staff had to be present and they had to follow through on what they had started. As Laura put it during interview: "you have to be here, you have to be having the conversations, you have to go visit people in their spaces, invite them into yours, there isn't a way round that". What's more, "the coincidence of conversations doesn't happen unless you're here".

Echoing Esposito's arguments about community, this focus on being open to other people and working with them over time, requires commitment and dedication. Moreover, it won't work if people think you are being instrumental and are only in it for the short term. Indeed, the fact that Lambeth Council only funded Open Works as a short term experiment - led by 'outsiders' - is a major weakness of the project itself. Such policy would need to be led by local people, and be supported for the long term to have lasting effect (and to realise the multiplier effects that were already emerging after just 18 months of the project). Indeed, the Civic Systems Lab report on the project emphasised the need for this long-term investment arguing that: "this platform approach is about making a long term commitment for institutions to work collaboratively with local residents to transform a place. The commitment to building a new system will be a minimum of three years, but this is not an 
approach with an exit strategy. It is about building a new type of mutual relationship for creating outcomes collaboratively over the long term" (Civic Systems Lab, 2015, 59).

At present, this model poses a major challenge to existing models of state-funding and service provision, even those committed to new ways of working - as in Lambeth - where Open Works was developed. Starting with community and working from there, without any certainty about the outcomes to be achieved, requires a leap of faith that is difficult (if not impossible) for funders and practitioners. Indeed, it is researchers, policy makers and professionals who are likely to find this approach most demanding: they are used to knowing what is best for local people and devising schemes to 'improve' the local population. Taking a different approach to community might allow them to see that people don't need or want to be 'improved' and if policy became a matter of being in relationship with local people and seeing what, if anything, they wanted to do, it reconfigures the role of the expert. This argument about co-production is in keeping with much of the rhetoric about public policy today (see Boyle and Harris, 2010; Boyle et al, 2010), and I explore the implications of this in relation to localism in the final section below.

\section{Conclusions}

This paper has argued that rather than seeing community as a 'thing' that is always subject to decline such that it requires constant rebirth - often through top down policy initiatives for public reform - community comprises the social relationships of life itself. This position challenges sociological scholarship and public policy discourse that bemoans the decline of community. Exemplified by Blackshaw's $(2010,16)$ recent textbook on the theme of community, a common view is that: "em-bracing community life will always be experienced by free men and women as a death of a kind, especially with all the possibilities that the wider world has to offer. What this suggests is that death and community today are inextricably linked - though the death, it should be noted, is always more likely going to be of the community rather than the individual". In this approach Blackshaw follows Bauman's (2001) position that community is necessarily pitted against individual freedom, liberalism and modernity. Yet if we rethink what we mean by community, nothing could be further 
from the truth. If, by community, we are referring to the necessary social relationships on which we depend, human being is community.

By applying these ideas alongside what Studdert (2005) refers to as 'microsociality' - the everyday enactment of social relationships in particular places - it is possible to rethink public policy. As demonstrated in the examples from Tower Hamlets and Lambeth in London, there is a different way to imagine community that works with the grain of local social life, aspirations and energy. Rather than devising a national-scale project or set of practices that can be imposed on 'poor' or 'deprived' or 'problem' people and places, as has been common in the past, the Open Works project demonstrated that it is possible to start with local people, explore their ideas and create new activity from the ground up.

In many ways, the Open Works 'platform approach' is in keeping with the ambitions of Government Ministers who have promoted the Big Society, localism and co-production since 2010 (Dorey and Farnett, 2012; HM Government, 2010). However, this approach to public policy has largely been about 'spatial liberalism', freeing up local actors to take initiatives that best meet the needs of their area within the parameters for action laid down by national legislation covering neighbourhood planning, the right to challenge and the right to buy (Clarke and Cochrane, 2013). While this permissive approach has created opportunities for local actors to take the initiative in a way that is very different from the more prescriptive regime that sought to promote the third way, the new localism, and double-devolution during the New Labour Governments between 1997 and 2010 (Davies, 2008; Stoker, 2011), many commentators have highlighted the dangers of its spatially uneven effects (Clifford, 2012; Mohan, 2012).

In this regard, the empirical examples presented in this paper present a possible 'next phase' for the development of this new approach to public policy and beyond that, a possible new paradigm for community-oriented public policy. The model provides a relatively low cost vehicle for engaging citizens in new developments in their area, building up a civic infrastructure that complements the creation of the neighbourhood forums that are already emerging as a result of neighbourhood planning. This approach would involve relatively modest investment in the staff required to foster connections and sustain local activity. However, realising the full potential of this approach would require a major shift in public policy thinking and practice across a wide range of organisations including national 
government, Local Authorities, housing associations, charities and civil society groups. As Civic Systems Lab $(20150,83)$ recognised in their analysis of the Open Works project: "Investing in a platform approach as a way of generating outcomes is different to most commissioning models. The typical commissioning cycle deployed across the UK requires a controlled process of service definition, tendering and evaluation. Platforms are designed to create the conditions for connections, emergence and outcomes, which is an entirely different process that cannot be pushed into the commissioning cycles described ... [it is about] designing a system of infrastructures that builds relationships." Working with local people to strengthen social relationships and develop new initiatives will require long-term, low-level funding and support. This paper has advocated that thinking what we mean by community is an important part of this process, helping to re-imagine public policy at the local liveable scale.

\section{Acknowledgements}

I am very grateful to David Studdert and Valerie Walkerdine for inviting me to the workshop on community and localism held at Cardiff University in April 2014 that stimulated this special issue of Sociological Review. I am also very grateful to the Leverhulme Trust for the research funding and to Nick Coke, Tessy Britton and Laura Billings for their invaluable contributions to the arguments made. The comments from three referees, the editors and Patrick Devine-Wright were extremely helpful in improving the paper.

\section{References}

Alinsky, S. D. (1941) Community analysis and organisation. American Journal of Sociology, $46,6,789-808$.

Amin, A. and Thrift, N. (2002) Cities: Reimagining the urban. Cambridge: Polity Press.

Bauman, Z. (2001) Community: Seeking safety in an insecure world. Cambridge: Polity Press.

Bernstein, R.J. (1992) The new constellation: The ethical-political horizons of modernity/postmodernity. Cambridge, Mass.: MIT Press. 
Bingham, N. (2006) Bees, butterflies and bacteria: Biotechnology and the politics of nonhuman friendship. Environment and Planning A, 38, 483-98.

Bissell, D. (2010) Passenger mobilities: Affective atmospheres and the sociality of transport. Environment and Planning D: Society and Space, 28, 270-289.

Blackshaw, T. (2010) Sage key concepts in community studies. London: Sage.

Bonnett, A. (2010) Left in the past: Radicalism and the politics of nostalgia. London: Continuum.

Boyle, D. and Harris, M. (2010) The challenge of co-production: How equal partnerships between professionals and the public are crucial to improving services. London: New Economics Foundation.

Boyle, D. Coole, A. Sherwood, C. and Slay, J. (2010) Right here, right now: Taking coproduction into the mainstream. London: NESTA.

Burgess, E. (1916) The social survey: A field of constructive service by Departments of Sociology. American Journal of Sociology, 21, 4, 492-500.

Calhoun, C. (1988) Community without propinquity revisited: Communications technology and the transformation of the urban public sphere. Sociological Inquiry, 68, 3, 373-397. Challenger, D.F. (1995) Durkheim through the lens of Aristotle. Rowman and Littlefield Publishers.

Charles, N. (2012) Families, communities and social change: Then and now. Sociological Review, 60, 438-456.

Charles, N. and Davies, C. A. (2005) Studying the particular, illuminating the general: community studies and community in Wales. Sociological Review, 53, 4, 672-690.

Civic Systems Lab (2015) Designed to scale: Mass participation to build resilient neighbourhoods. Available from: http://www.theopenworks.org/ (last accessed 2.11.15) Clarke, N. (2013) Locality and localism: A view from British human geography. Policy Studies, $34,5-6,492-507$. 
Clarke, N. and Cochrane, A. (2013) Geographies and politics of localism. Political Geography, $34,10-23$.

Clifford, D. (2012) Voluntary sector organisations working at the neighbourhood level in England: Patterns by local area deprivation. Environment and Planning A, 44, 1148-64.

Crow, G. and Allan, G. (1994) Community Life: An introduction to local social relations. Hemel Hempstead: Harvester Wheatsheaf.

Cruddas, J. and Rutherford, J. (2014) One nation: Labour's political renewal. London: One Nation Register.

Davies, J. (2008) Double-devolution or double-dealing? The Local Government White Paper and the Lyons Review. Local Government Studies, 34, 1, 3-22.

Day, G. and Murdoch, J. (1003) Locality and community: Coming to terms with place. Sociological Review, 41, 1, 82-111.

Dennis, N. (1958) The popularity of the neighbourhood community idea. Sociological Review, 6, 2, 191-206.

Devine-Wright, P. (2015) Local attachments and identities: A theoretical and empirical project across disciplinary boundaries. Progress in Human Geography, 39, 4, 527-30.

Dorey, P. and Farnett, M. (2012) No such thing as the Big Society? The Conservative Party's unnecessary search for 'narrative' in the 2010 General Election. British Politics, 7, 4, 389417.

Engel, S. (2002) Saul D. Alinsky and the Chicago School. Journal of Speculative Philosophy, $16,1,50-66$.

Esposito, R. (2010) Communitas: The origin and destiny of community. Stanford: Stanford University Press.

Esposito, R. (2013) Terms of the political: Community, immunity, biopolitics. New York: Fordham University Press.

Finlayson, A. (2002) The horizon of community in A. Finlayson and J. Valentine, (eds) Politics and post-structuralism: An introduction. Edinburgh: Edinburgh University Press, 161-175. 
Gauntlett, D. (2011) Making is connecting: The social meaning of creativity from DIY and knitting to you tube and web 2.0. Cambridge: Polity Press.

Gergen, K. (2014) From mirroring to world-making: Research as future forming, Journal for the Theory of Social Behaviour, 1-24.

Gibson-Graham, J.K. (2006) A post-capitalist politics, Minneapolis: University of Minnesota Press.

Gibson-Graham, J.K. (2008) Diverse economies: performative practices for 'other worlds'. Progress in Human Geography, vol. 32, pp. 613-632.

Greenhough, B. (2014) More-than-human-geographies. In A. Paasi, N. Castree, R. Lee, S. Radcliffe, R. Kitchin, V. Lawson and C. W. J. Withers (eds.) The Sage Handbook of Progress in Human Geography. SAGE: London, 93-120.

Hall, P. (1999) Social capital in Britain. British Journal of Political Science, 29, 417-461.

Harney, L. McCurry, J. Scott, J. and Wills, J. (2016) Developing 'process pragmatism' to underpin engaged research in human geography, Progress in Human Geography (forthcoming).

HM Government (2010) Decentralisation and the Localism Bill: An essential guide. London: HM Government.

Hickson, K. (2013) The localist turn in British politics and its critics. Policy Studies, 34, 4, 408421.

Hinchcliffe, S. and Whatmore, S. (2006) Living cities: Towards a politics of conviviality. Science as Culture, 15, 123-38.

Howell, P. (1993) Public space and the public sphere. Environment and Planning D: Society and Space, 11, 303-322.

Jones, H. Neal, S. Mohan, G. Connell, K. Cochrane, A. and Bennett, K. (2015) Urban multiculture and everyday encounters in semi-public franchised café spaces. Sociological Review, $63,644-661$.

Kenny, M. (2014) The politics of English nationhood. Oxford: Oxford University Press. 
Koch, R. and Latham, A. (2012) Rethinking urban public space: Accounts from a junction in West London. Transactions of the Institute of British Geographers, 37, 515-29.

London Borough of Lambeth (2011) The co-operative council: Sharing power - A new settlement between citizens and state. The Cooperative Council Citizens' Commission, London.

Laurier, E. and Philo, C. (2006) Cold shoulders and napkins handed: Gestures of responsibility. Transactions of the Institute of British Geographers, 31, 193-207. Lawless, P. Foden, M. Wilson, I. and Beatty, C. (2010) Understanding area based regeneration: The New Deal for Communities programme in England. Urban Studies, 47, 2, 257-275.

Maclntyre, A. (1981) After virtue: A study in moral theory. University of Notre Dame Press. Manzo, L. C. and Perkins, D. D. (2006) Finding common ground: The importance of place attachment to community participation and planning. Journal of Planning Literature, 20, 4, 335-350.

Mohan, J. (2012) Commentary: Geographical foundations of the Big Society. Environment and Planning A, 44, 1121-29.

Nancy, J.L. (1991) The inoperative community. Minneapolis: University of Minnesota Press. Nancy, J.L. (2000) Being singular plural. Stanford: Stanford University Press.

Pahl, R. (2005) Are all communities communities in the mind? Sociological Review, 53, 4, 621-640.

Panelli, R. and Welch, R. (2005) Why community? Reading difference and singularity with community. Environment and Planning A, 37, 1589-1611.

Park, R. E., Burgess, E. W. and McKenzie, R.D. (1925) The City. Chicago: University of Chicago Press.

Peck, J. and Tickell, A. (1994) Jungle law breaks out: neoliberalism and global-local disorder. Area, 26, 4, 317-26. 
Peck, J. and Tickell, A. (2012) Apparitions of neoliberalism: revisiting 'Jungle law breaks out'. Area, 44, 2, 245-49.

Popke, J. (2009) Geography and ethics: non-representational encounters, collective responsibility and economic difference. Progress in Human Geography, 33, 1, 81-90.

Popke, J. (2010) The spaces of being in-common: Ethics and social geography, in S.J. Smith, R. Pain, S.A. Marston and J.P. Jones III (eds) The Sage Handbook of Social Geographies, London: Sage, 435-454.

Putnam, R. (2000) Bowling Alone: The collapse and revival of American community. New York: Simon and Shuster.

Reason, P. and Bradbury, H. (2001) (eds) The handbook of action research: Participatory inquiry and practice. London: Sage.

Rorty, R. (1989) Contingency, irony and solidarity, Cambridge: Cambridge University Press.

Sampson, R. J. (2012) Great American City: Chicago and the enduring neighbourhood effect. Chicago: Chicago University Press.

Savage, M. (2010) Identities and social change in Britain since 1940: The politics of method. Oxford: Oxford University Press.

Stoker, G. (2011) Was local governance such a good idea? A global comparative perspective. Public Administration, 89, 1, 15-31.

Studdert, D. (2005) Conceptualising community: Beyond the state and individual. Basingstoke: Palgrave Macmillan.

Taylor, C. (1989) Sources of the self: The making of modern identity. Cambridge, MA: Harvard University Press.

Tomaney, J. (2013) Parochialism: A defence. Progress in Human Geography, 37, 5, 658-672. Walkerdine, V. and Studdert, D. (2013) Community as micro-sociality and the new localism agenda. Research paper for the AHRC Connected Communities programme available from: http://abergavennycommunity.co.uk/wp-content/uploads/2014/07/CC-DiscussionPaperabergavenny30thfinal.pdf 
Wellman, B. (1996) Are personal communities local? A Dumptarian reconsideration. Social Networks, 18, 347-54.

Wilson, J. (2012) Letting Go: How Labour can learn to stop worrying and trust the people. Fabian Ideas 632. London: Fabian Society.

Wills, J. (2012) The geography of community and political organisation in London. Political Geography, 31, 114-126.

Wills, J. (2013) Politics and place, in Featherstone, D and Painter, J. (eds) Spatial politics: Essays for Doreen Massey. Oxford: Wiley-Blackwell, 135-145. 